\title{
Android-Based Expert System Application to Determine Math Learning Styles of Elementary School Students in Surakarta
}

\author{
Rayung Wulan, Achmad Sarwandianto, Nur Alamsyah, Aulia Ar Rakhman Awaludin
}

Universias Indraprasta PGRI, Jakarta, Indonesia

\begin{abstract}
This Android-based expert system application was created to assist teachers in analysing student learning styles and identification of student learning styles that are easy to transfer knowledge in schools. The instrument used was the results of a questionnaire to measure learning style variables and student assessment variables in receiving mathematics lessons. The Android-based expert system application was designed based on student learning style questionnaire, the questionnaire was validated, and internal consistency reliability, set the instrument items and then collected in the rules and decision trees. The results of the questionnaire were taken from 6 elementary schools in Surakarta. The inference method used in this calculation is the forward chaining method, looking at the results of the decision tree as outlined in the expert system application. The Android-based expert system application is very effective and efficient in analysing student learning styles.
\end{abstract}

Keywords - Applications, Maths learning styles, Android

\section{Introduction}

Primary school is the most basic level of formal education in Indonesia. Elementary school is taken within 6 years, starting from grade 1 to grade 6 . Primary school students are generally aged 7 years to 12 years.

DOI: $10.18421 /$ SAR32-03

https://doi.org/10.18421/SAR32-03

Corresponding author: Rayung Wulan,

Universias Indraprasta PGRI, Jakarta, Indonesia.

Email: utha2578@gmail.com

Received: 07 May 2020.

Revised: 10 June 2020.

Accepted: 15 June 2020.

Published: 30 June 2020.

(c) BY-NC-ND (C) 2020 Rayung Wulan at al; published by UIKTEN. This work is licensed under the Creative Commons Attribution-NonCommercial-NoDerivs 3.0 License.

The article is published with Open Access at www.sarjournal.com
Elementary schools are run by the government and the private sector and since the enactment of regional autonomy in 2001, the management of the State Target Elementary school. In Indonesia, which was previously under the Ministry of National Education, it is now the responsibility of district governments, whereas the Ministry of National Education only acts as a regulator in the field of national education standards. The objective of the basic unit of education level is to lay the foundation for intellect, personality, noble character and the skills to live independently and attend further education. To achieve the educational objectives at the level of the basic education unit, the role of the teacher is demanded in the learning process so that students have a balance between cognitive, affective and psychomotor behaviour. The role of the teacher in providing and providing meaningful learning experiences is really needed by students, teachers who know the learning styles of students can understand longer learning and improve student learning outcomes at school.

In a world that is rapidly changing, creativity is a determinant of excellence. With the rapid growth of information technology, mobile technology is one of the easiest and fastest efficient tools to support and help in this era[1], along with the development of Android technology in communication and information media that provides convenience in everything. Android is an operating system for Linux-based cellular phones such as smartphones and tablet computers. It provides an open platform for developers to create their own applications for use by a variety of mobile devices. The competitive power of a nation is also determined by the creativity of its human resources. Creative individuals can view a problem from a variety of different perspectives. This perspective allows the individual to obtain various suitable alternative solutions to solve the problem. To make it easier for teachers to determine students' learning styles, an application that can help the analysis process for educators to analyze student learning styles takes the form of software applications that can work as well as education observers work as alternatives in analysing student 
learning styles. The Android-based expert system application is very helpful in finding information about learning styles based on the type felt until finding conclusions based on diagnosis results in the form of information about the learning patterns and students' creativity.

\section{Literature Review}

A smartphone is a mobile phone that has the ability of use and function that resembles a computer. Smartphone usage is now ubiquitous across much of the global population, with the smartphone offering a vast range of applications (apps) that help to extend human cognition[2]. There is no factory standard that determines the meaning of a smartphone. For some people, a smartphone is a phone that works using all operating system software that provides standard and fundamental relationships for application developers. For others, a smartphone is just a phone that provides advanced features such as electronic mail, internet and the ability to read electronic books (e-books) or there is a keyboard (both as finished and connected out) and a VGA connector. In other words, a smartphone is a small computer that has the capabilities of a telephone. Most devices that are categorized as smartphones use a different operating system. In terms of features, most smartphones fully support e-mail facilities with complete personal control functions. Other functions can include a miniature QWERTY keyboard, touch screen or Dpad, camera, roster settings, speed counter, software and hardware navigation, the ability to read business documents, music player, photo explorer and view video clips, internet explorer, or just secure access to open company email. The feature most often found in smartphones is the ability to store as many names as possible, unlike ordinary cell phones which have a maximum limit on storing name lists. The hardware we use is Lenovo a6000 + because this device is equipped with several features that allow us to run applications that we have designed to operate. Because what we have designed is an application for Android-based smartphones, so the smartphones needed must be Android-based. In addition, using benchmark software, a recommended specification has been formulated for the hardware of an Android device that achieves the same behavior as an iOS device[3]. Android Studio is an Integrated Development Environment - Integrated Development Environment (IDE) for Android application development, based on IntelliJ IDEA. Besides being an IntelliJ code editor and a powerful developer tool, Android Studio offers more features to increase your productivity when creating android applications, for example:
- A flexible Gradle-based manufacturing system

- A fast and feature-rich emulator

- A unified environment for development for all Android devices

- Instant Run to push changes to running applications without creating a new APK

- Code templates and GitHub integration to create the same application features and import sample code

- Extensive testing tools and frameworks

- Lint tools to improve performance, usability, version compatibility, and other problems

Expert systems are systems that seek to adopt human knowledge to computers that are designed to solve problems like an expert. Expertise is transferred from experts to a computer. This knowledge is then stored in the computer. When the user runs the computer to get information, the expert system will ask for facts and can make reasoning (inference) so that it comes to a conclusion. Then, the expert system provides an explanation and conclusions on the results of consultations that have been carried out previously. With this expert system, ordinary people can either solve their problems or just look for quality information that can only be obtained with the help of experts in their fields. This expert system can also help the activities of experts as assistants who have the required knowledge.

The expert system component consists of 5 components :

1. Knowledge Base

- Core of the expert system program

- Is a representation of knowledge from an expert

- Composed of facts in the form of objects and conditions which are information about how to generate new facts from known facts.

2. Inference Engine

- The parts that contain the mechanism of thinking functions and patterns of system reasoning used by an expert.

- This mechanism will analyze a particular problem and then look for the best answer or conclusion.

- Select relevant knowledge in order to reach a conclusion

- Begin tracking by matching the rules in the knowledge base with the facts in the list of facts that are stored on the basis of the knowledge on the hard disk.

3. User Interface

- The connecting part between the expert system and the user

- There will be a dialogue between the program and the user 
- The program will ask questions in the form of a menu driven, natural language statements, and graphics interface style. The expert system program will draw conclusions based on user answers.

4. Development Engine Part of the expert system as a facility to develop inference machines and the addition of a knowledge base that will be carried out by knowledge engineers or must have expertise in understanding how experts apply their knowledge in solving a problem, and are also able to extract explanations (knowledge acquisition) about knowledge from experts when discovering new knowledge and rules in solving various problems

5. Reasoning techniques There are two techniques in reasoning (interfaces) :

- Backward tracking (backward chaining) that starts reasoning from the conclusion (goal), by looking for a set of hypotheses to the facts that support a set of hypotheses.

- Forward chaining starts from a collection of facts by looking for rules that match the existing assumptions/ hypotheses leading to conclusions.

Mathematics develops numerical languages that allow quantitative measurements to be carried out. This quantitative nature increases the predictive power and control of science to provide more exact answers that enable precise and accurate problem solving[4]. Mathematics is the science of patterns and sequences. As something that is practical, mathematics does not talk about molecules and cells, but it discusses numbers, possibilities, shapes, algorithms and changes[5]. As a science with abstract objects, mathematics depends on logic, not on observation as the standard of truth, although it uses observation, simulation and even experimentation as a tool to find out the truth ". Mathematics discusses the numbers in the algorithm as outlined in the human mindset so that it is instrumented into the application of an expert system.

Learning style is a unique and consistent way in which students absorb and process the information they have obtained. Student learning styles are grouped into three types namely visual, auditory, and kinesthetic[6]. Visual type learning styles use their sense of sight to help them learn. In general, students have all three types of learning styles, but there is one of the most dominant they have. Most students are not familiar with the learning style so they have not been able to apply it optimally. Utilization of learning resources in mathematics, is a way to pay attention to learning mathematics in the classroom, student learning styles make it easy for students to concentrate fully when learning.

\section{Methodology}

Methodology really determines a research, because it involves the right way in data collection, data analysis and conclusion of the research results. The methodology that the author uses to solve various problems :

\section{Observation}

Searching for data / information by making direct observations of the object under study.

\section{Interview}

Obtaining data with questions and answers directly to teacher and students about learning styles in Maths lessons, and consultation with three experts in the analysis of mathematical learning styles

\section{Library Research Method}

This type of research is conducted by collecting data related to the topic of the problem from the title that the author made. This is done by reading books, papers, e-journals, and articles to get a sufficient theoretical foundation.

\section{Field Research Methods}

The method by visiting elementary school by looking at the responses of these teachers. It enables to understand the workings of the anatomy of the human body using Android to be able to follow it well.

Expert System Development Methods A good expert system must have the following characteristics [7].

- Having reliable information facilities.

- Easy to modify.

- Can be used in a variety of computers.

- Have the ability to learn to adapt.

This research using the method of forward chaining for the manufacture of expert systems diagnostic learning styles of elementary school students. Forward chaining is a data driven approach. In this approach tracking starts from input information, and then tries to draw conclusions. Forward tracking is looking for facts that are in accordance with the IF part of the IF-THEN rules[8].

The steps that must be taken in creating a rulesbased forward chaining system are :

1. Problem Identification

This stage covers the problem domain and knowledge acquisition.

2. b) B. Input Data Definition

The forward chaining system requires initial data to start inference.

3. c) C. Definition of Data Control Structure Complex applications require additional premises to help control the activation of rules.

4. d) D. Writing the Initial Code 
This stage is useful to determine whether the system has captured the domain of knowledge effectively in a good rule structure.

5. e) E. System Testing

System testing is carried out with several rules to test the extent to which the system runs correctly.

6. f) F. Interface Design

The interface is one important component of a system. Interface design is made together with the creation of a knowledge base.

7. g) G. System Development

System development includes the addition of interfaces and knowledge in accordance with the prototype system.

8. h) H. System Evaluation

At this stage the system is tested with the real problem. If the system is not running well, redevelopment is carried out.

\section{Conclusion}

One level of success in the learning process can be measured through students' learning styles and creativity. Learning styles and students' creativity are different from each other, they have their own creativity and style in learning or exploring the knowledge they have in learning. Some students will experience difficulties in the learning process because they do not know how to study well. In line with the opinion of Students look learning difficulties because they do not know their learning styles[9]. Learning style is an attitude in which a student can explore his knowledge in a directed and creative way. So to improve learning achievement in improving the quality of education a teacher must know student learning styles.

Creativity is an action or attitude that exists in humans which is then poured in human selfinteraction with the surrounding environment. Self creativity comes from the conscience as outlined in life, especially the pattern of learning about something. The importance of creativity or the ability to think creatively in relation to efforts to improve the quality of education is indeed very logical, the ability to think creatively is considered as a very vital source for a nation. Therefore, the education system (formal, non-formal, informal) should be aimed at developing the quality of children's thinking so that in the process of cognitive and intelligence development they obtain opportunities optimally as well. In general, teachers know this from the help of counseling guidance teachers, where counseling guidance teachers know the creativity and learning styles of students by distributing questionnaires, this of course requires a very long time. However, this research will be given in the form of an expert system application that can help teachers to more practically analyse student learning styles and creativity using the forward chaining method, the way it works is to find or track the character of student learning styles and learning creativity, taking into account facts which then lead to conclusions based on facts. This method is the opposite of the backward chaining method which searches from the hypothesis to the facts to support the hypothesis. By using the forward chaining method, the explanation is not very facilitated because subgoals are not known explicitly before the conclusion is found[10]. Forward chaining is also called bottom-up reasoning or bottom-up consideration, because this method considers the evidence at the bottom level, the facts, leading to conclusions at the top level based on facts. From these problems, the author intends to design an instrument of learning style and creativity of elementary school children with a forward chaining method that is able to help teachers and parents in learning several types of learning styles and creativity in children.

\section{User Interfase Design}

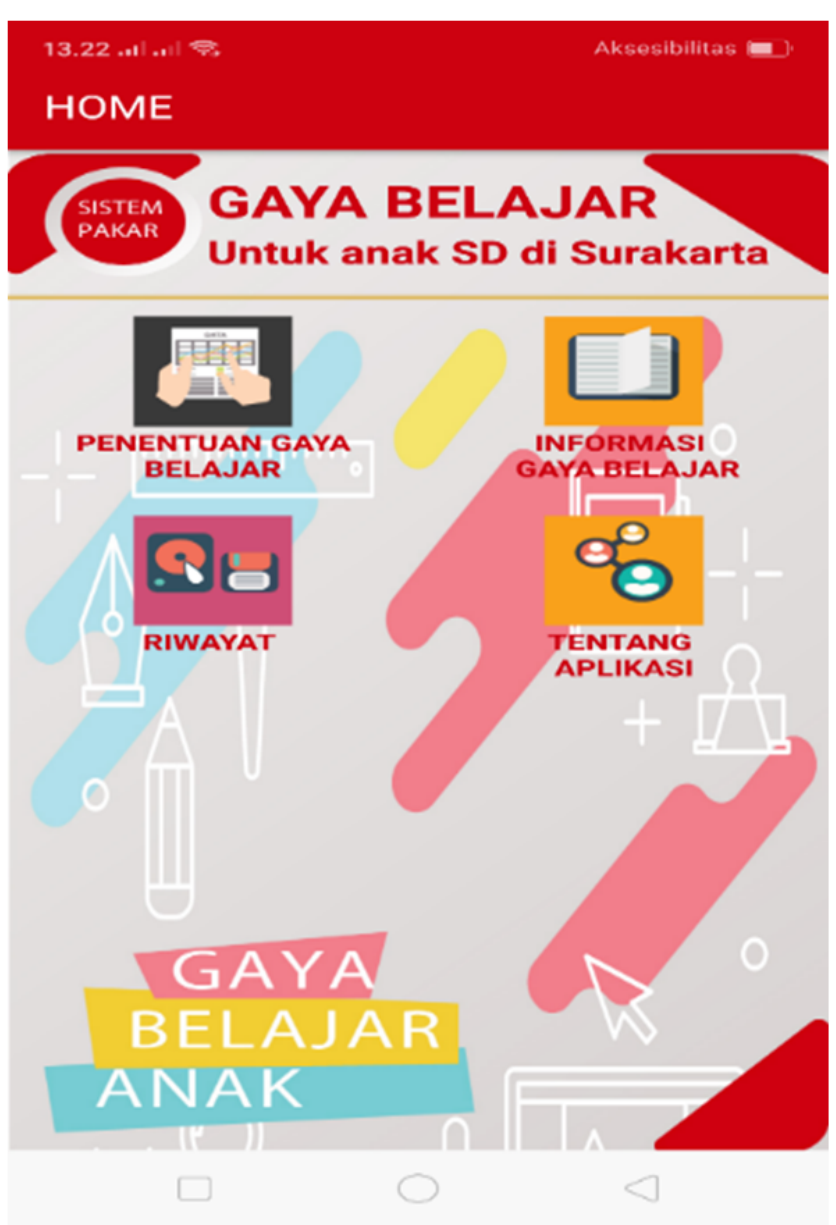

Figure 1. Main page display

Home Main page There are four menu choices upon entering the application, Determination of Learning Styles; Learning Style Information; History; About Application. 


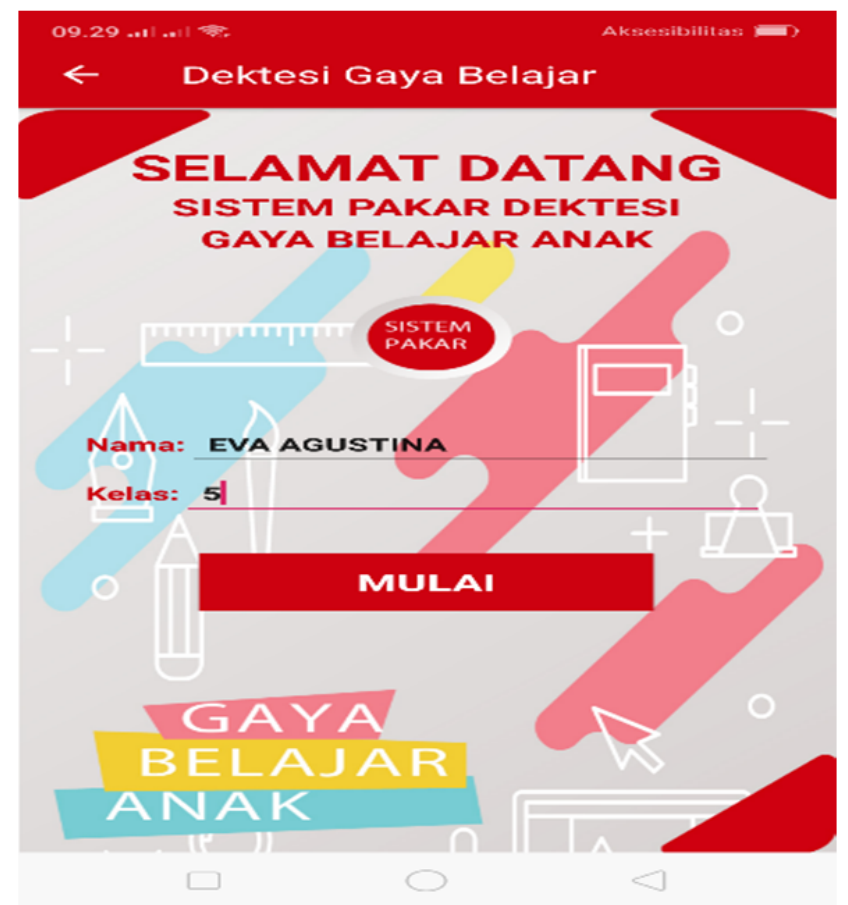

Figure 2. Select determination of learning styles

In the Learning Style Determination Menu there are 2 information that must be inputted. Input Name and Class begin.

Press the "Mulai" button then some questions will be displayed which must be filled in accordance with the user's learning.

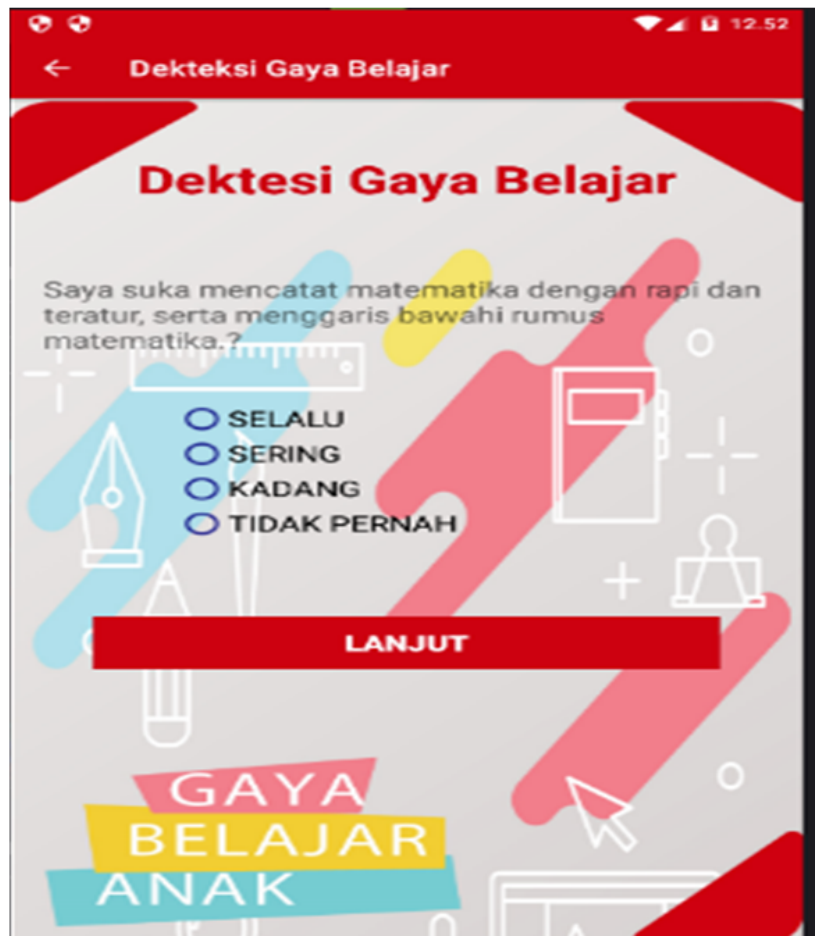

Figure 3. Learning style detection display

Each question consists of four answer choices, "Selalu", "Sering”, "Kadang", “ Pernah". Then click continue for each question.

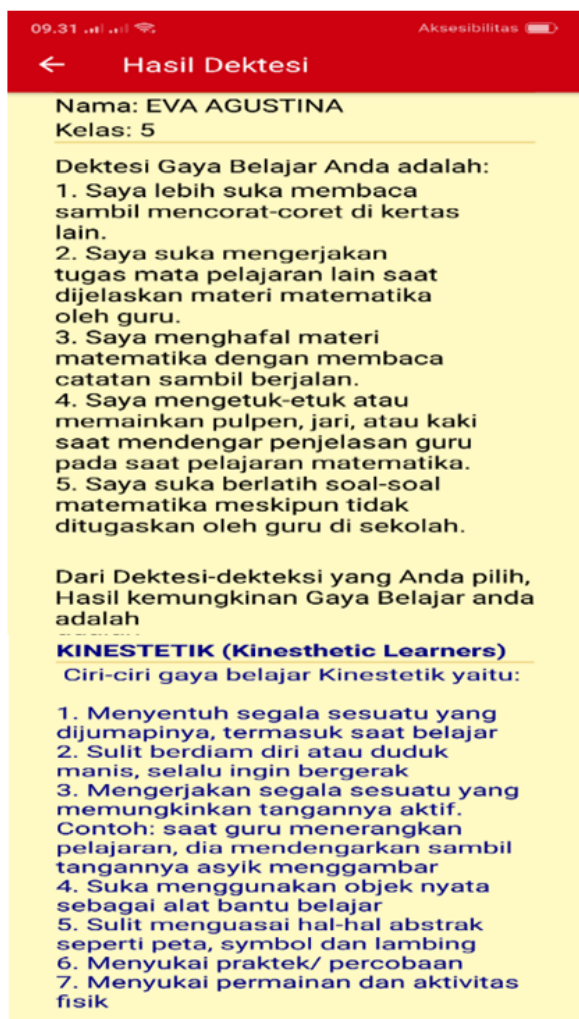

Figure 4. Detection results display

In the learning style information menu, there are 3 VISUAL, AUDITORY and KINESTETIC sub menus. Each menu contains information on each learning style.

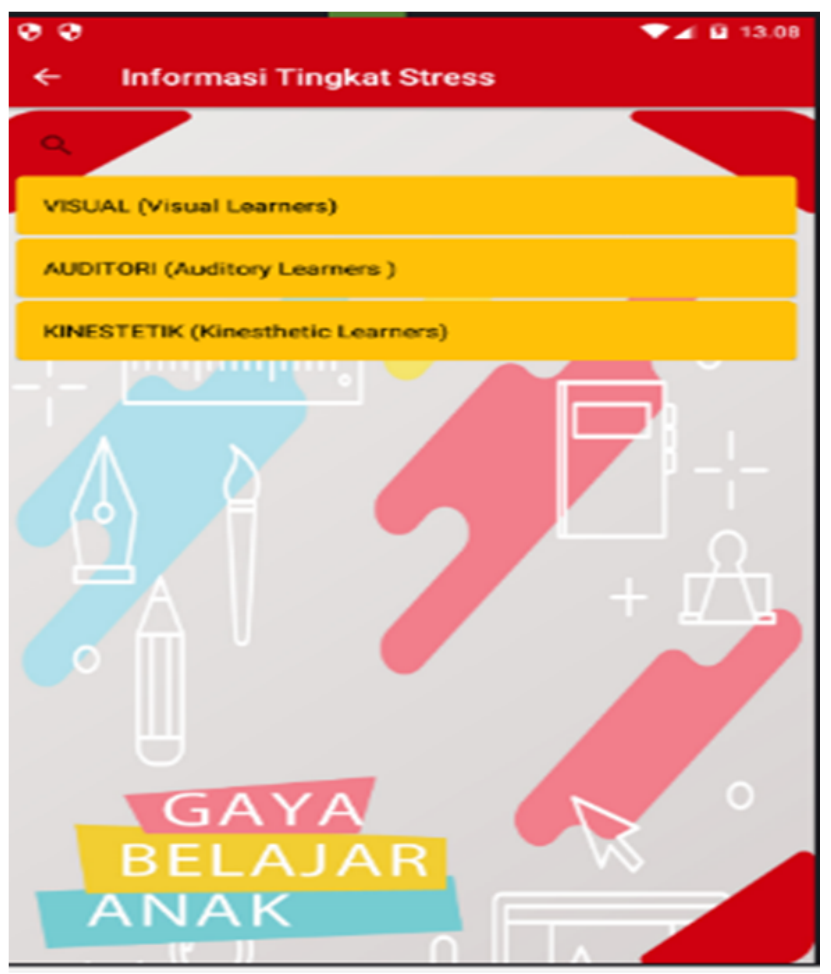

Figure 5. Information display 
In the History menu there is a list containing the results of consultations that have been carried out by the application. The delete button is used to delete the history of either one particular data or the entire history data.

\section{Conclusion}

The Android-based expert system application can be used anywhere and at any time, as a material for determining student learning styles and learning creativity, helping teachers in the learning process in class in improving learning achievement to improve the quality of national education. With the application of this expert system, elementary school teachers in Surakarta can find out various student learning styles, and student characteristics in learning mathematics.

\section{Acknowledgements}

Appreciation and thanks to Directorate and Devotion The Research, Strengthening Research and Development Director General, Ministry, Research Technology and Higher Education who have financed Desentralisasi Research activities Penelitian Dasar Unggulan Perguruan Tinggi (PDUPT) 2018 with a title "Expert system of it for analysis learning style and creativity of the elementary school (SD) in Surakarta”. Thank you for LLDikti III Jakarta, Indonesia, and research institutes and devotion the community Universitas Indraprasta PGRI, Jakarta, Indonesia. Who have assisted with to conduct this research through research work contract pt inco was number 30/AKM/MONOPNT/2019.

\section{References}

[1] Rattanachai, R., Sreekaewin, P., \& Sittichailapa, T. (2015). Development of Thai Rice Implantation Recommend System Based on Android Operating System. Procedia-Social and Behavioral Sciences, 197, 1048-1052.

[2] Clark, A., \& Chalmers, D. (1998). The extended mind. analysis, 58(1), 7-19.

[3] Suzuki, S. N., Akimoto, Y., Hirata, K., Ishihara, M., Kameyama, R., Yamaguchi, M., \& Yajima, K. (2019). Development of Android Version Active Textbook System. Procedia Computer Science, 159, 2258-2266.

[4] Karim, A. (2011). Penerapan metode penemuan terbimbing dalam pembelajaran matematika untuk meningkatkan pemahaman konsep dan kemampuan berpikir kritis siswa sekolah dasar. Jurnal pendidikan, 1(1), 21-32.

[5] Mulqueeny, K., Kostyuk, V., Baker, R. S., \& Ocumpaugh, J. (2015). Incorporating effective elearning principles to improve student engagement in middle-school mathematics. International Journal of STEM Education, 2(1), 1-14.

[6] Asiry, M. A. (2016). Learning styles of dental students. The Saudi Journal for Dental Research, 7(1), 13-17.

[7] Azhar, S., Sari, H. L., \& Zulita, L. N. (2014). Sistem Pakar Penyakit Ginjal Pada Manusia Menggunakan Metode Forward Chaining. Jurnal Media Infotama, 10(1), 16-26.

[8] Guntur, G., \& Merlina, N. (2016). Sistem Pakar Diagnosa Kerusakan pada Mesin Pendingin Ruangan dengan Metode Forward Chaining. Jurnal Pilar Nusa Mandiri, 12(1), 102-108.

[9] Esa, A., Radzali, M. A., Misdi, M., \& Jaafar, M. Z. (2009). Congruency of mind between lecturers and students in engineering disciplines. Asian Social Science, 5(8), 78-86.

[10] Giarratano, J. C. (1998). Expert systems: principles and programming. Book. PWS Publishing Company. 